Относительно преступления, совершенного несовершеннолетним, срок давности должен быть сокращен вдвое. Данное указание закреплено в статье 94 УК РФ.

Также необходимо обратить внимание на статью 90УК РФ. Так, несовершеннолетний может быть освобожден от уголовной ответственности за совершение преступления небольшой или средней тяжести. Но только при условии, что его перевоспитание возможно без назначения уголовного наказания с помощью принудительных мер воспитательного характера. Но, к сожалению применение указанных мер на практике применяется достаточно редко, несмотря на рекомендацию для судов применять их взамен мер уголовного наказания [2].

Самым распространённым видом освобождения от наказания является условнодосрочное наказание. На практике оно применяется при совершении всех видов преступлений и ко всем видам осужденным. Выражается данный вид наказания в виде того, что после фактического отбытия осужденным к моменту освобождения указанного законом срока, судпризнает то, что для своего исправления лицо не нуждается в полном отбытии назначенного наказания и способно доказать это в течение испытательного срока. Условно-досрочное освобождение возможно только в отношении лица, осужденного к лишению свободы.

Таким образом, все виды освобождения несовершеннолетнего от уголовной ответственности основываются на применении мер принудительного воспитательного воздействия. Обеспечение данных видов освобождения от наказания находится в компетенции специально уполномоченных органов.

Освобождение от юридической ответственности представляет собой средство индивидуализации этой ответственности за совершение какого-либо противоправного деяния. Развитие рассматриваемого института говорит о реализации принципа гуманизма, на котором основано построение любого правового государства, в том числе и в нашей стране.

1. Уголовный кодекс Российской Федерации от 13.06.1996 № 63-Ф3 (ред. от 19.02.2018) // [Электронный ресурс] СПС Консультант Плюс.

2. Бахвалова Л.А. Актуальные проблемы эффективности системы мер уголовно-правового воздействия, применяемых в отношении несовершеннолетних по УК РФ // Вестник Омского университета. Серия Право. - 2012. - №2 (31). - С.245- 253.

3. Келина С.Г., Кудрявцев В.Н. Принципы советского уголовного права. - М.: Наука, 1988. - 176 с.

4. Ревин В.П. Уголовное право России / М.: Альянс, 1998. - 326 с.

5. Фаизуллина Д.Р. История развития института освобождения от уголовной ответственности и наказания в России. // Актуальные проблемы экономики и права. - 2012. - №2(6). Режим доступа: http://cyberleninka.ru/article/n/istoriya-razvitiya-instituta-osvobozhdeniyaot-ugolovnoy-otvetstvennosti-inakazaniya-v-rossii\#ixzz4gV33gF99.

\title{
Стулов Ф.Н., Коряченцова С.И. \\ Особенности правового регулирования деятельности по постановке особо охраняемых природных территорий регионального значения на государственный кадастровый учет
}

Комитет по природным ресурсам Ленинградской области, СанктПетербургский юридический институт (филиал), Академия Генеральной прокуратуры Российской Федерации

doi:10.18411/spc-20-03-2018-07

(Россия, Санкт-Петербург)

idsp: 000001:spc-20-03-2018-07

\section{Аннотация}

Статья посвящена рассмотрению особенностей исполнения законодательства об особо охраняемых природных территориях. Обосновывается актуальность 
осуществления и повышения эффективности контрольных и надзорных полномочий за исполнением законодательства на особо охраняемых природных территориях. А также обозначаются проблемы в реализации федерального законодательства об особо охраняемых природных территориях при постановке особо охраняемых природных территорий регионального значения на государственный кадастровый учет.

Ключевые слова: прокуратура, градостроительство, особо охраняемые природные территории, нарушения законодательства, земельные участки, кадастровый учет.

В настоящее время вопросы обеспечения экологической безопасности государства относится к числу приоритетных направлений деятельности. Эта работа востребована обществом. В 2017 году, в Год экологии и особо охраняемых природных территорий принят комплекс мер по установлению законности.

Контролирующими и иными органами проведены масштабные работы по устранению нарушений при рассмотрении сигналов общественности о нарушениях экологического законодательства.

В ряде регионов не определены границы особо охраняемых природных территорий (далее - ООПТ) и их охранные зоны, имелись случаи незаконного распоряжения землями.

Обеспечение законности в деятельности ООПТ является одной из первостепенных задач для органов прокуратуры в экологической сфере. По результатам рассмотрения мер прокурорского реагирования органами государственной власти, местного самоуправления определены границы 356 ООПТ и их охранных зон [1].

Особо охраняемые природные территории относятся к объектам общенационального достояния. Министерство природных ресурсов и экологии Российской Федерации осуществляет государственное управление в области организации и функционирования особо охраняемых природных территорий федерального значения [2].

Стратегическое значение ООПТ - сохранение всех форм жизни на Земле. Всего в Российской Федерации по состоянию на 01.01.2016 г. насчитывалось более 13 тысяч ООПТ федерального, регионального и местного значения, общая площадь которых составляет 207,5 млн га (с учетом морской акватории), что составляет $12,1 \%$ от площади территории России. По данным Департамента государственной политики и регулирования в сфере охраны окружающей среды по состоянию на 01.01.2016 г. в Российской Федерации имеется 103 государственных природных заповедника, 48 национальных парков, 64 государственных природных заказника федерального значения, 2243 государственных природных заказников регионального значения, более 8 тыс. памятников природы (в том числе 17 федерального значения), а также более 2,8 тыс. ООПТ иных категорий регионального и муниципального значения, установленные субъектами Российской Федерации в рамках действующего законодательства в сфере ООПТ [3].

Из более чем 13 тыс. существующих на сегодняшний день в России ООПТ, подавляющая часть имеет региональный статус (89\%) и лишь 295 (включая дендрологические парки и ботанические сады) имеют федеральный статус [4].

Отсутствие сведений, о границах особо охраняемой природной территории приводит к нарушениям требований земельного законодательства, связанным с предоставлением физическим и юридическим лицам в собственность, аренду, пользование, владение земельных участков в границах существующих особо 
охраняемых природных территорий, и нарушениям, в связи с этим, режима их использования.

Кроме того, нарушение действующего законодательства об особо охраняемых территориях неизбежно приведет к негативному влиянию на окружающую среду и потере природных объектов.

В соответствии с частью 18 статьи 32 Федерального закона «О государственной регистрации недвижимости» обязательным приложением к документам, направляемым в орган регистрации для внесения сведений о границах ООПТ в ЕГРН, является карта (план) объекта землеустройства, подготовленная в соответствии с требованиями, установленными Федеральным законом от 18 июня 2001 года № 78-Ф3 «О землеустройстве».

В соответствии со статьей 20 Федерального закона «О землеустройстве» карта (план) объекта землеустройства является документом, отображающим вграфической и текстовой формах местоположение, размер, границы объекта землеустройства и иные его характеристики. Карта (план) объекта землеустройства составляется с использованием сведений государственного кадастра недвижимости, картографического материала, материалов дистанционного зондирования, а также по данным измерений, полученных на местности. Форма карты (плана) объекта землеустройства и требования к ее составлению устанавливаются Правительством Российской Федерации. Названные форма и требования утверждены постановлением Правительства Российской Федерации от 30.07.2009 № 621.

Для обоснованного включения в государственный фонд данных документации, сформированной в отношении границ ООПТ, на территориальные органы Росреестра возложена обязанность по проверке документов:

на комплектность представленной документации, в силу требований пункта 9 Порядка описания местоположения границ объектов землеустройства, утвержденного приказом Минэкономразвития России от 03.06.2011 № 267;

на соответствие карты (плана) объекта землеустройства, содержащейся в документации, форме и требованиям, установленным постановлением Правительства Российской Федерации от 30.07.2009 № 621.

Учитывая положения действующего законодательства необходимо учитывать, что для обеспечения точного описания границ ООПТ как объекта землеустройства и определения точных координат характерных точек границ ООПТ должны использоваться материалы геодезических и картографических работ и данные измерений, полученных на местности.

С учетом положений ч. 5 ст. 72 Федерального закона от 13.07.2015 № 218-Ф3 «О государственной регистрации недвижимости», вступившего в действие с января 2017, указанный Федеральный закон применяется к правоотношениям, возникшим после дня его вступления в силу. Закон по правоотношениям, возникшим до дня его вступления в силу, применяется к тем правам и обязательствам, которые возникнут после дня его вступления в силу.

В настоящее время действующим законодательством, статьей 32 Федерального закона от 13.07.2015 № 218-Ф3 «О государственной регистрации недвижимости», установлено, что органы государственной власти и органы местного самоуправления обязаны направлять в орган регистрации прав документы в случае принятия ими решений (актов) об установлении или изменении границ особо охраняемой природной территории.

В ранее действовавшем Федеральном законе от 24.07.2007 № 221-Ф3 «О государственном кадастре недвижимости» сведения об особо охраняемых природных 
территориях вносились в государственный кадастр недвижимости как информация о границах зон с особыми условиями использования территорий.

Представляется целесообразным рассмотреть вопросы предоставления органами власти в Росреестр, документов для внесения сведений в Единый государственный реестр недвижимости. Так, в случае принятия органами власти решений (актов) об утверждении правил землепользования и застройки либо о внесении изменений в указанные правила, если такими изменениями предусмотрено установление или изменение градостроительного регламента, установление или изменение границ территориальных зон, а также вопросы установления или изменении границ населенного пункта, такие сведения должны быт направлены в органы регистрации прав.

Исполнение законодательства об охране окружающей среды в городских и сельских населенных пунктах в конкретном городском округе (поселении) зависит от состояния окружающей среды, экономической ситуации, а также уровня экологоправовой культуры соответствующих должностных лиц.

Комплексная охрана экологических систем населенных пунктов в рамках исполнения градостроительного законодательства, безусловно важное направление, поскольку выбросы и сбросы в окружающую среду городских хозяйствующих субъектов, размещение в границах города бытовых и производственных отходов, загрязнение городских природных ресурсов приводят к совокупному негативному эффекту. Определенные виды вредного воздействия, будучи по отдельности малоопасными для окружающей среды, соединяясь с другими, образуют экологически опасные вещества. В связи с чем исполнение законодательства об охране окружающей среды должно осуществляться не на отдельных частях территории населенного пункта при ведения хозяйственной деятельности, а должны быть разработаны меры по комплексной охране территории всего населенного пункта с учетом негативного на всю территорию.

Грамотная организация и проведение комплексных работ по территориальному планированию и зонированию территории населенных пунктов, а также решение вопросов о безопасном размещении опасных производств является залогом эффективной работы органов власти, в том числе в сфере экологии.

Кроме того, вопросы размещения отходов, строительства, реконструкции жилой и промышленной застройки, эксплуатации промышленных объектов, также должны находиться в поле зрения должностных лиц органов власти.

Поскольку в границах населенного пункта могут располагаться особо охраняемые природные территории, либо сам населенный пункт может располагаться в границах ООПТ, исполнение законодательства в данной сфере требует особого внимания.

Граница муниципального образования отделяет его территорию от территорий других муниципальных образований или межселенных территорий.

Правовое определение понятия границы населенного пункта содержится в ст. 83 Земельного кодекса Российской Федерации. Границы городских, сельских населенных пунктов отделяют земли населенных пунктов от земель иных категорий.

Земельным кодексом Российской Федерации установлены ограничения границ городских, сельских населенных пунктов, так границы муниципальных образований не могут пересекать или выходить за их границы, а также пересекать границы земельных участков, предоставленных гражданам или юридическим лицам.

В силу требований ч. 6 ст. 36 Градостроительного кодекса Российской Федерации (далее - ГрК РФ) установлены специальные случаи, когда применительно к некоторым территориям градостроительные регламенты не устанавливаются, 
поскольку на данных землях вообще запрещено возводить какие-либо объекты капитального строительства. В связи с тем, что застройка подобных земель находится под запретом, отсутствует необходимость устанавливать градации по разрешенным видам режима использования земельных участков, поскольку вся территория характеризуется единым функциональным статусом.

В соответствии с ч. 7 ст. 36 ГрК РФ использование земельных участков, на которые действие градостроительных регламентов не распространяется или для которых градостроительные регламенты не устанавливаются, определяется уполномоченными федеральными органами исполнительной власти, уполномоченными органами исполнительной власти субъектов Российской Федерации или уполномоченными органами местного самоуправления в соответствии с федеральными законами.

Согласно подпункту 8 п. 1 ст. 1 и пункту 2 ст. 7 ЗК РФ правовой режим земель определяется исходя из их принадлежности к той или иной категории и разрешенного использования в соответствии с зонированием территорий и требованиями законодательства. Правовой режим земель складывается из определения категории земель, территориального зонирования земель, специальных требований земельного законодательства, к которым относятся установление публичных земельных сервитутов и установление ограничений прав на землю. Деление земель на категории является основным способом определения правового режима земель. Главный критерий их разграничения - различное целевое назначение, определяющее общую цель, в соответствии с которой они используются.

Решения об отнесении конкретных участков земли к особо охраняемым природным территориям с установлением на них особого правового режима принимаются федеральными органами исполнительной власти, органами исполнительной власти субъектов РФ и органами местного самоуправления. В соответствии с земельным законодательством в целях создания новых и расширения существующих земель особо охраняемых природных территорий органы государственной власти субъектов Российской Федерации вправе принимать решения о резервировании земель, которые предполагается объявить землями особо охраняемых природных территорий, с последующим изъятием таких земель, в том числе путем выкупа, и об ограничении на них хозяйственной деятельности.

Организация ООПТ влечет за собой ограничение прав владельцев, пользователей земельных участков, расположенных в границах ООПТ.

Универсальным ограничением является ограничение в обороте земель в границах ООПТ, которое влечет запрет на предоставление земельных участков в границах ООПТ в частную собственность, если иное не предусмотрено федеральными законами; запрет на изменение целевого назначения земельных участков или прекращение прав на них для нужд, противоречащих установленному режиму особой охраны.

Представляется необходимым контрольными и надзорными мероприятиями охватить не только стадию застройки территории, но и исполнение природоохранного законодательства при планировании, размещении, эксплуатации отдельных объектов и осуществлении планирования застройки территории.

Целью указанных мероприятий является обеспечение должного уровня жизнедеятельности граждан, снижение вредного воздействия на окружающую среду и организация исполнения природоохранного законодательства.

В данном случае цели прокурорского надзора и контрольные полномочия целиком и полностью совпадают с целями закрепленными в градостроительном законодательстве. Так, силу положений ст. 9 Градостроительного кодекса Российской 
Федерации территориальное планирование направлено на определение в его документах назначения территорий исходя из совокупности социальных, экономических, экологических и иных факторов в целях обеспечения устойчивого развития территорий, развития инженерной, транспортной и социальной инфраструктур, обеспечения учета интересов граждан и их объединений, Российской Федерации, субъектов РФ, муниципальных образований.

$$
* * *
$$

1. http://genproc.gov.ru/smi/news/genproc/news-1275006/ Дата обращения 15.01.201

2. Постановление Правительства РФ от 29.05.2008 № 404 (ред. от 28.01.2011) «О Министерстве природных ресурсов и экологии Российской Федерации»

3. Государственный доклад «О состоянии и об охране окружающей среды Российской Федерации в 2015 году». - М.: Минприроды России; НИА-Природа. - 2016. - С. 180.

4. Государственный доклад «О состоянии и об охране окружающей среды Российской Федерации в 2015 году». - М.: Минприроды России; НИА-Природа. - 2016. - С. 181.

\section{Усманов Р.Ф. \\ Предупреждение и разрешение конфликта интересов в органах внутренних дел Российской Федерации}

Академия Управления МВД России (Россия, Москва)

doi:10.18411/spc-20-03-2018-08

idsp: 000001:spc-20-03-2018-08

В последние годы в Российской Федерации разработан и реализуется комплекс мер, направленных на разрешение конфликта интересов в системе государственной службы. Данная работа велась и ведется по трем основным направлениям: преодоление личных конфликтов интересов, то есть связанных с персональными интересами агента - должностного лица; преодоление организационных конфликтов интересов, связанных с наличием противоречивых требований к государственным служащим со стороны самого государства как организация; совершенствование организации административного учета как инструмента внутригосударственного и общественного контроля за действиями служащих.

Так, для решения проблем персонального конфликта интересов государством предлагается использовать следующие меры. Во-первых, повышение информационной открытости органов государственной власти. Под информационной открытостью органов государственной власти, включая правоохранительные органы, предлагается понимать относительную доступность в получении информации гражданами (организациями и объединениями) об их деятельности. Подчеркивается, что принятый 9 февраля 2009 г. Федеральный закон РФ от 9 февраля 2009 г. №8-Ф3 «Об обеспечении доступа к информации о деятельности государственных органов и органов местного самоуправления» внесет существенный вклад в расширение информационной открытости органов государственной власти, включая органы внутренних дел. Немаловажным в этой связи представляется и создание механизмов общественного контроля за деятельностью органов государственной власти.

Во-вторых, речь идет о создании системы административных регламентов, используя которые можно будет судить о правомерности действий должностного лица. Без наличия таких регламентов информационная открытость и административный учет будут малоэффективны.

В-третьих, речь идет о сокращении вмешательства государства в экономику и общественную жизнь. 